\title{
Using the Cluster Approach to Waste Management - Blagoevgrad Region
}

\author{
Nikolinka Atnasova \\ Department of Geography, Ecology and Environmental Protection, \\ Faculty of Mathematics and Natural Sciences, South-West University, Bulgaria
}

Copyright $\bigcirc 2017$ by authors, all rights reserved. Authors agree that this article remains permanently open access under the terms of the Creative Commons Attribution License 4.0 International License

\begin{abstract}
Clusters are a way to organize thinking on many policy areas beyond the usual needs of the economy as tsyalo. Klasterat is one of the tools of competitiveness and helps to clarify the priorities and direction of policy in science and technology, education and many other areas. Prevention of waste generation has the highest priority in the management hierarchy, while landfilling is in the group of the lowest. Given the financial situation of Bulgaria, which is in transition and is still in crisis, our country's national policy is aimed at reconciling the two priorities in the most appropriate way. The Ministry of Environment and Water has adopted an approach for building new landfills on a regional basis, with the maximum utilization of recyclable waste meeting the European requirements. Both on a global scale and in the European Union, the shortage of raw materials and energy resources is increasing. This has also re-evaluated the waste management policy in our country based on sustainability and regionality. Following the European model, the Ministry of Environment and Water adopted the approach for the construction of landfills for waste disposal from several neighboring municipalities and meeting the overriding regulatory requirements laid down in Decree №209 / 2009 - "To provide funding for the construction of regional systems Waste management, regional pre-treatment systems for municipal waste and the closure of municipal landfills ". For the purposes of the Decree, a "Regional Waste Management System" is a set of measures that municipalities jointly take to ensure that the total amount of waste generated on the territory of the region is collected separately, transported, stored, treated and disposed of in an environmentally sound manner. The report examines the practical steps in building a cluster policy related to environmentally sound waste management Blagoevgrad Region, covering the municipalities of Blagoevgrad, Simitli, Kyustendil, Rila, Kocherinovo and Boboshevo. Future research aims at creating a cluster model "Resource recovery and mitigation Climate change, "which we hope will have a multiplier effect on future regional landfills for domestic waste disposal in Bulgaria.
\end{abstract}

Keywords Waste Management, Cluster, Environment

\section{Introduction}

"Clusters are a way to organize thinking about many policy areas beyond the usual needs of the economy as a whole. Cluster-based thinking can help clarify priorities and target policy towards science and technology, education and training, export promotion and foreign investment, and many other areas. [1] Cluster theories give clearer and more effective dimensions of the impact of competitiveness policy. Effective solutions often require cooperation between different bodies involved in the formed cluster. Cluster - is a self-organizing network / group of competing companies that:

- $\quad$ are technology and / or supply-related;

- $\quad$ Produce complementary products;

- use co-production factors / technologies;

- cooperate or cooperate in vertical or horizontal "chains". [2]

Clusters typically represent specific networks of interconnected but remaining competitive companies, specialized suppliers, companies and service organizations and related administrative authorities and other non-governmental institutions in a region. [3]

The institutionalization of clusters of interconnected clusters in our country started with a decision of the Council of Economic Growth at the Council of Ministers in spring 2004. It identifies four key industrial sectors in which to work on initiating and promoting the creation of similar associations in Bulgaria.

Most of the mentioned clusters are managed on the basis of long-term relationships, formed in the form of non-profit associations (according to the Law on Non-Profit Legal Entities). Such an approach to institutionalization excludes situational behavior and implies vision and perspective in action, and also gives members of the web a certainty about future joint intentions. It allows the generation of subsequent 
positive economic and social effects for cluster participants and the region (s) as a whole.

According to official data, by 2015261 clusters have been registered in Bulgaria, of which 150 are in Sofia. The rest are located in the major cities of the country: Plovdiv, Varna, Burgas, Rousse.

- A large part of the clusters created in the country aim to group interests. Their main task is to create conditions for improving the competitiveness of the Bulgarian economy.

- In the new programming period 2014-2020. the Operational Program "Innovation and Competitiveness" focuses on organizational and administrative strengthening of clusters in the country. [4]

\section{Layout of the Problem and Set Goals}

Both on a global scale and in the European Union, the shortage of raw materials and energy resources increases. This has also re-evaluated the waste management policy in our country, based on regionality, sustainability and maximum utilization. Following the European model, the Ministry of the Environment and Water has adopted the approach of building regional landfills for waste disposal involving several neighboring municipalities and meeting the higher regulatory requirements. The infrastructure of the regional landfills also envisages the construction of segregating installations and land fillings for bio-waste composting in order to:

- Separation of separately collected packaging waste;

- separating recyclable waste into the total waste stream;

- elimination of the accidental waste stream from the general waste stream;

- maximum reduction of the quantities of waste to be disposed of at regional landfills;

- $\quad$ reducing the amount of greenhouse gases generated by the decomposition of the biodegradable fraction of the waste. [5]

Various types of waste are generated on the territory of Blagoevgrad municipality: construction, industrial and household. Collection, transport and landfilling of waste in the municipality is carried out by the biostroy trade company with $100 \%$ municipal participation. The generated municipal waste from all the settlements in the municipality is deposited at a municipal landfill site for non-hazardous waste on the territory of the village of Bouchino.

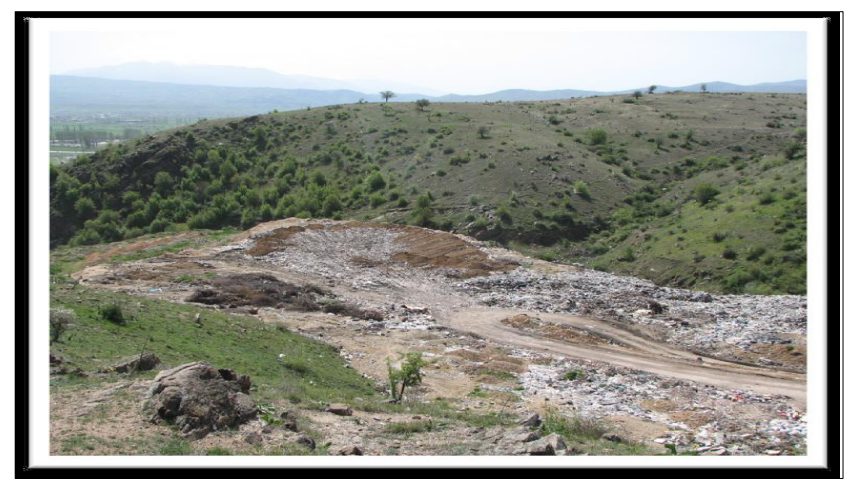

Figure 1. The existing municipal depot / personal photo/

The existing municipal depot of the municipality has been operating since 1996. Plans have been approved to bring it into line with the legislation, the measures have expired, and the landfill will be exploited until the regional waste treatment system is built.

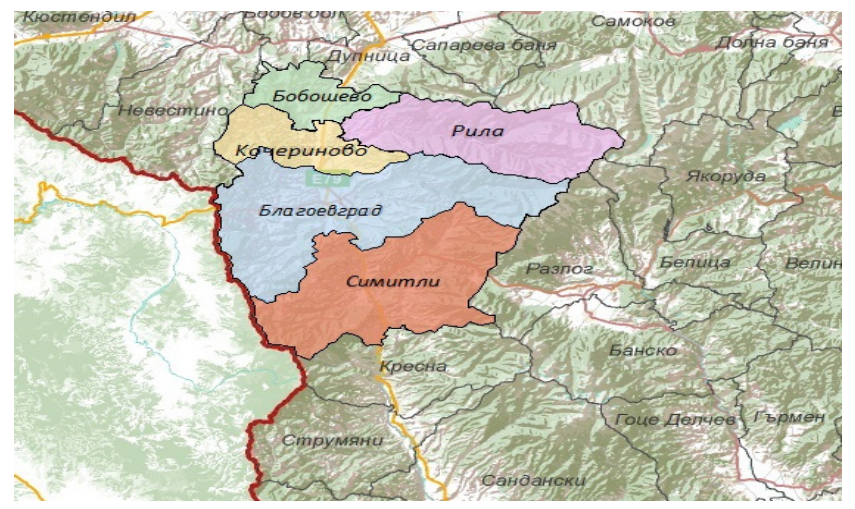

Figure 2. The municipalities that will participate in the regional landfill

The waste disposal facility at this stage and for the five municipalities do not meet the regulatory requirements, especially for the Rila, Kocherinovo, Simitli and Boboshevo municipalities.

Contrary to the norms for the protection of human health, it is common practice not regulated by the landfill to collect and sort manually separate fractions of the mixed waste for further transfer to collection points for payment.

The specialized municipal waste collection equipment, which serves the municipal systems for the provision of the municipal waste collection and disposal service, is morally and physically obsolete. Reinvestments in the purchase of new equipment are hardly done.

In the National Waste Management Program (NWW) 2014-2020, the country's general strategic goal is: "Society and Business that Do not Deposit Waste". The strategic objectives to ensure the achievement of the overall strategic goal are: 
- Objective 1: Reduce the harmful impact of waste by preventing its formation and encouraging its reuse

- Objective 2: Increase the quantities of recycled and recovered waste by creating conditions for the construction of a network of facilities for treatment of the entire quantity of waste generated to reduce the risk to the population and the environment

- Goal 3: Waste management, ensuring a clean and safe environment

- Goal 4: Making the public a key factor in implementing the waste management hierarchy.

During the new programming period 2014-2020, the Operational Program "Innovation and Competitiveness" focuses on the organizational and administrative strengthening of the clusters in the country [5]. There is no cluster of waste in the country so far that would facilitate their regional governance. For the Blagoevgrad Region, waste management is planned from the municipalities: Blagoevgrad, Simitli, Kocherinovo, Boboshevo and Rila. Creating a cluster model "Resource recovery and climate change mitigation" would lead to lower municipal spending due to the geographic concentration of certain companies and organizations. Reducing costs for participants in the Resource Waste and Climate Change Cluster model is expected to be the result of:

- Improving the quality of waste management by the five municipalities;

- Offering new products and services;

- Higher skilled labor;

- Recovery and recycling of waste that will be stimulated by cluster formation;

- Geographically concentrated multiplier effect;

- Increased demand and supply of products and services;

- Internal networking with trainers and scientific and production organizations;

- Improved infrastructure and communications.

The main goals pursued with the creation of the cluster are:

- Establishment and development of a network of joint ties between cluster partners and the stakeholder network in the field of municipal waste management and their treatment;

- Facilitate access to science, technology, and experience sharing;

- Creating new and upgrading existing services and products to enhance partner competitiveness, including boosting the "value chain";

- Support entrepreneurship and innovation in the cluster of work and create conditions for effective commercialization of research results;

Mitigating climate change by limiting greenhouse gases. due to the separation of biodegradable waste from the total waste stream to be disposed of .[6]
Ordinance No. 6 on the conditions and requirements for construction and operation of landfills and other facilities and installations for recovery and disposal of waste (promulgated, SG No. $80 / 13.09 .2013$, in force as of 13.09.2013, Amended and supplemented, No. 13 of 7.02.2017.

The biggest disadvantage for the development of clusters in Bulgaria is the insufficient participation of universities, research institutes and centers, schools and other educational institutions in the clusters concerned, which has a bearing on their technological development, the transfer of innovation and the training of highly qualified staff.

For the creation of the Cluster "Waste" model it is necessary to analyze the existing state of their management at the municipal level. For the Blagoevgrad Region, a survey was carried out on the quantities, composition of the waste and the state of the currently existing landfills of the municipalities of Blagoevgrad, Simitli, Kocherinovo, Boboshevo and Rila that will participate in the regional system. The Regional Waste Management Association Blagoevgrad is an independent, voluntary, non-governmental organization, bringing together the following municipalities on a regional basis:

- The main objectives of "Regional Waste Management Association - Blagoevgrad" are:

- The joint construction, management and operation by the municipalities of the association of a regional landfill for the disposal of non-hazardous waste in a property owned by Blagoevgrad municipality, falling within the boundaries of the existing landfill of Blagoevgrad Municipality;

- Establishment of a waste management system consisting of the regional landfill and / or other waste treatment facilities, according to the legal requirements;

- Effective treatment of waste in compliance with the requirements of the Waste Management Act, the secondary legislation and the National Waste Management Plan;

- Applying the municipalities of the regional association for financing projects in the field of waste management from the European funds, the state budget, the Enterprise for management of environmental protection activities at the MoEW or other national public sources of financing;

- Improving the quality of the services for collecting, transporting and disposing of municipal waste and the waste treated as waste;

- Maximum conversion of waste into resources;

- Optimization of the waste management processes in order to reduce the cost of the service for collecting, transporting and disposing of the municipal waste and the waste treated as waste;

- Transparency and accountability of waste management processes; 
- Stimulating and supporting the activity of the individual citizens for participation in the waste management processes;

- Encourage dialogue and interaction between the state, local authorities, business organizations in solving waste management problems. [7]

Each municipality member of the regional association will participate in the costs of construction of the regional landfill and its putting into operation, of the costs of construction of waste treatment facilities by making monetary (property) contributions. In providing funding for a project for the different stages of the construction of the regional landfill and / or other waste treatment facilities, the municipality contributes a percentage of the contribution of the regional association to the implementation of the project.

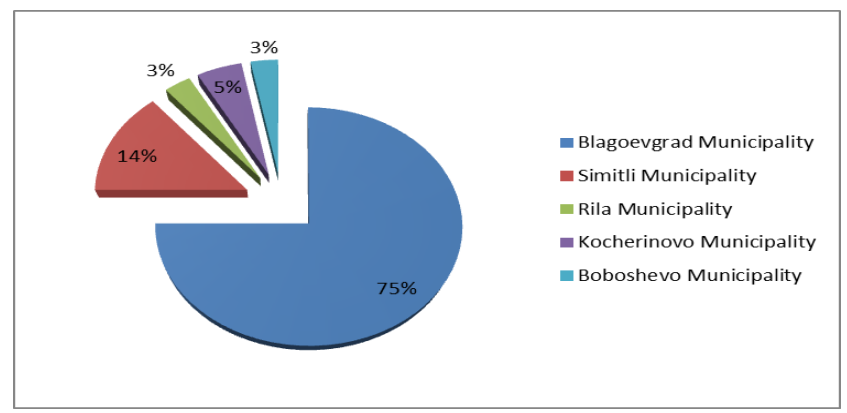

Figure 3. The percentage participation of each municipality member of the Regional Association/ personal data processing/

\section{Conclusions}

Business clusters can be used as a locomotive for regional smart specialization in Bulgaria because they involve real elements existing in the areas of innovation infrastructure. Moreover, the development and creation of new clusters are a prerequisite for developing links between education, training and business. Clusters can contribute to setting standards of competence in the regional waste management. In this area there are a number of challenges in terms of improving separate collection and recycling management processes of recycling and recovery of a number of waste streams, as well as awareness and motivation of the population. On one hand, attention should be paid to the substitution of conventional - exhaustible resources with new technological solutions or the use of recycled raw materials, and on the other - to be stimulated reuse that can be applied mainly in regional waste management model for cluster "Resource recovery of waste and mitigate climate change." So Blagoevgrad region realize its contribution to sustainable and effective waste management in the country as a whole in accordance with the requirements of European legislation, which in turn will contribute to the realization of major Community priorities for cohesion policy: sustainable development and improving the attractiveness of regions by improving accessibility, ensuring adequate quality and level of services and preserving their environmental potential.

\section{REFERENCES}

[1] NATIONAL STRATEGY FOR DEVELOPING CLUSTERS 2007-2013

[2] Zhelyazkov, K.B. Vanev, G. Shivarov, "Competitiveness of Companies and Clustering Approach", / European Entrepreneur Day, 04.11.2004/, 2004

[3] Zakova, E. Clusters - ways of their formation and work. Cluster overview in Bulgaria. 2007

[4] Institute for Market Economics, REGIONAL PROFILESDEVELOPMENT INDICATORS, 2015

[5] Organ Solvell, Goran Lindqvist, Christian Ketels, The Cluster Initiative Greenbook, 2003

[6] WASTE MANAGEMENT PROGRAM OF BLAGOEVGRAD MUNICIPALITY 2015 - 2020, Municipality of Blagoevgrad, November 2015

[7] NATIONAL CLUSTER DEVELOPMENT STRATEGY, Working version: May, 2006. 